\title{
The CB1 Cannabinoid Receptor Can Sequester G-Proteins, Making Them Unavailable to Couple to Other Receptors
}

\author{
Clemente Vásquez and Deborah L. Lewis \\ Department of Pharmacology and Toxicology, Medical College of Georgia, Augusta, Georgia 30912-2300
}

\begin{abstract}
We tested the hypothesis that human CB1 cannabinoid receptors (hCB1) can sequester $\mathrm{G}_{\mathrm{i} / \mathrm{o}}$-proteins from a common pool and prevent other receptors from signaling. Human CB1 cannabinoid receptors were expressed in superior cervical ganglion (SCG) neurons by microinjection of hCB1 cDNA. Expression of hCB1 cannabinoid receptors abolished the $\mathrm{Ca}^{2+}$ current inhibition by endogenous pertussis toxin-sensitive $G_{i / o^{-}}$ coupled receptors for norepinephrine (NE) and somatostatin (SOM) but not by endogenous pertussis toxin-insensitive $\mathrm{G}_{\mathrm{s}}$ coupled receptors for vasoactive intestinal polypeptide. Signaling by NE was rescued by expression of $\mathrm{G} \alpha_{\mathrm{oB}}, \mathrm{G} \beta_{1}$, and $\mathrm{G} \gamma_{3}$. Expression of mGluR2 metabotropic glutamate receptors, another pertussis toxin-sensitive G-protein-coupled receptor, had no effect on the signaling by NE or SOM. Some hCB1 receptors were constitutively active because the cannabinoid receptor inverse agonist SR 141617A enhanced the $\mathrm{Ca}^{2+}$ current. Some
\end{abstract}

The role of the cannabinoid receptor in brain function is thought to be related to the effects of marijuana (Cannabis sativa), which include euphoria, hypothermia, analgesia, appetite stimulation, and memory impairment. The brain CB1 cannabinoid receptor is a member of the G-protein-coupled receptor superfamily (Matsuda et al., 1990; Gérard et al., 1991). Heterologous expression studies have shown that the CB1 cannabinoid receptor inhibits adenylyl cyclase, activates an inwardly rectifying $\mathrm{K}^{+}$channel, and inhibits $\mathrm{N}$ - and Q-type $\mathrm{Ca}^{2+}$ channels by coupling to pertussis toxin-sensitive G-proteins (Matsuda et al., 1990; Mackie et al., 1995; Pan et al., 1996). In hippocampal neurons, cannabinoid receptors inhibit glutamatergic synaptic transmission and $\mathrm{Ca}^{2+}$ currents and enhance the A-type $\mathrm{K}^{+}$current (Deadwyler et al., 1993, 1995; Twitchell et al., 1997; Shen and Thayer, 1998). Acetylcholine release from the guinea pig myenteric plexus (Coutts and Pertwee, 1997) and hippocampal slice (Gifford and Ashby, 1996), GABA release from hippocampal slice (Katona et al., 1999), and norepinephrine release from sympathetic nerves has been shown to be inhibited by CB1 cannabinoid receptors (Ishac

Received June 7, 1999; revised Aug. 18, 1999; accepted Aug. 24, 1999.

This work was supported by a grant from the National Institutes of Health, National Institute on Drug Abuse Grant DA10350 to D.L.L. We thank Dr. Tom I. Bonner (National Institute of Mental Health, Bethesda, MD) for the human CB1 cannabinoid receptor cDNA, Dr. Shigetada Nakanishi (Kyoto University, Kyoto, Japan) for the mGluR2 receptor cDNA, Dr. Melvin Simon (Caltech, Pasadena, CA) for $\mathrm{G} \alpha_{\mathrm{oB}}, \mathrm{G} \beta_{1}$, and $\mathrm{G} \gamma_{3} \mathrm{cDNA}$, and Sanofi Recherche (Montpellier, France) for SR 141716A. We also thank Dr. Nevin Lambert and Dr. Clare Bergson for helpful discussions.

Correspondence should be addressed to Dr. Deborah L. Lewis, Department of Pharmacology and Toxicology, Medical College of Georgia, 1120 15th Street, Augusta, GA 30912-2300. E-mail: DLewis@mail.mcg.edu.

Dr. Vásquez's present address: Centro Universitario de Investigaciones Biomedicas, Universidad de Colima, 28000 Colima, Colima, Mexico.

Copyright (C) 1999 Society for Neuroscience 0270-6474/99/199271-10\$05.00/0
hCB1 receptors also appear to be precoupled to $\mathrm{G}_{\mathrm{i} / \mathrm{o}}$-proteins because the cannabinoid agonist WIN 55,212-2 decreased the $\mathrm{Ca}^{2+}$ current at a time when no G-proteins were available to couple to $\alpha_{2}$-adrenergic and somatostatin receptors. In SCG neurons microinjected with a lower concentration of hCB1 cDNA, the effect of SR 141716A was reduced, and the response to NE and SOM was partially restored. Subsequent to the application of SR $141716 \mathrm{~A}$, the $\mathrm{Ca}^{2+}$ current inhibition by NE and SOM was abolished. These results suggest that both the active and inactive states of the hCB1 receptor can sequester $\mathrm{G}_{\mathrm{i} / \mathrm{o}}$-proteins from a common pool. Cannabinoid receptors thus have the potential to prevent other $G_{i / o}$-coupled receptors from transducing their biological signals.

Key words: calcium channels; G-proteins; cannabinoid receptor; G-protein-coupled receptors; patch clamp; ion channels; CB1; constitutively active receptors

et al., 1996). Thus, the CB1 cannabinoid receptor functions to modulate neuronal excitability and neurotransmitter release.

The development of the CB1 receptor antagonist SR 141716A (Rinaldi-Carmona et al., 1994) led to the discovery that CB1 cannabinoid receptors can exist in a tonically active state. SR 141716A produced effects that were opposite those of cannabinoid agonists, indicating that SR 141716A was acting as an inverse agonist (Bouaboula et al., 1997; Landsman et al., 1997; MacLennan et al., 1998; Pan et al., 1998). We have shown that SR $141716 \mathrm{~A}$ increased $\mathrm{N}$-type $\mathrm{Ca}^{2+}$ currents in SCG neurons expressing CB1 receptors by inhibiting tonically active CB1 receptors (Pan et al., 1998). Bouaboula et al. (1997) reported that SR $141716 \mathrm{~A}$ inhibited the activation of mitogen-activated protein kinase by the pertussis toxin-sensitive tyrosine kinase receptors insulin and insulin-like growth factor in cells transfected with hCB1 receptors. These authors hypothesized that SR 141716A converts a tonically active hCB1 receptor into an active negative state in which the receptor is coupled to a GDP-bound G-protein. Those G-proteins trapped by the inverse agonist would be unavailable to couple to other receptors.

The present study tested the hypothesis that hCB1 cannabinoid receptors can sequester G-proteins from a common pool and prevent other G-protein-coupled receptors from signaling. We predicted that hCB1 receptors would deplete a pool of pertussis toxin-sensitive G-proteins such that signaling by other pertussis toxin-sensitive G-protein-coupled receptors would be disrupted. Disruption of signaling would be confined to pertussis toxinsensitive $G_{i / o}$-coupled receptors and not to $G_{s}$-coupled receptors. We also tested the hypothesis that the hCB1 cannabinoid receptors are capable of sequestering $\mathrm{G}_{\mathrm{i} / \mathrm{o}}$-proteins in two naturally occurring receptor states, an active state coupled to $\mathrm{G}_{\mathrm{i} / \mathrm{o}}$, and an 
inactive state precoupled to $\mathrm{G}_{\mathrm{i} / \mathrm{o}}$-proteins in their inactive GDPbound form. For precoupling to occur, the hCB1 receptor would be predicted to have a uniquely high affinity for $\mathrm{G}_{\mathrm{i} / \mathrm{o}}$-proteins.

\section{MATERIALS AND METHODS}

Molecular biological procedures. The human brain cannabinoid receptor cDNA (from Dr. Tom I. Bonner, Laboratory of Cell Biology, National Institute of Mental Health, Bethesda, MD) was subcloned into the mammalian expression vector pCI (Promega, Madison, WI) as previously described (Pan et al., 1998). The metabotropic glutamate receptor mGluR2 cDNA (from Dr. Shigetada Nakanishi, Kyoto University, Kyoto, Japan) was subcloned into pCI using the SalI and NotI restriction sites. G-protein subunit cDNAs for $\mathrm{G} \alpha_{\mathrm{oB}}, \mathrm{G} \beta_{1}$, and $\mathrm{G} \gamma_{3}$ (in pCIS, pCDM8.1, and pcDNA1, respectively) were obtained from Dr. Melvin Simon (Caltech, Pasadena, CA). Preparation of plasmid DNA was accomplished with a plasmid prep kit (Qiagen, Santa Clarita, CA).

Neuron preparation and microinjection. SCG neurons were enzymatically isolated from adult male Wistar rats (150-300 gm) following methods previously described (Ikeda et al., 1995) in accordance with the Committee on Animal Use for Research and Education. Neurons were allowed to attach to poly-D-lysine-coated $35 \mathrm{~mm}$ culture dishes for 4-5 hr before microinjection. The nuclei of single SCG neurons were microinjected with plasmids containing hCB1 cDNA, mGluR2 metabotropic glutamate receptor $\mathrm{cDNA}$, or $\mathrm{G} \alpha_{\mathrm{oB}}, \mathrm{G} \beta_{1}$, and $\mathrm{G} \gamma_{3} \mathrm{cDNA}$. Plasmids were diluted in TE buffer (10 mM Tris- $\mathrm{HCl}, \mathrm{pH} 8$, and $1 \mathrm{~mm}$ EDTA) to final injection concentrations of $10-200 \mathrm{ng} / \mu \mathrm{l}$. The pEGFP-N1 plasmid (10 $\mathrm{ng} / \mu \mathrm{l})$ containing the coding sequence of the green fluorescent protein (Clontech, Palo Alto, CA) was used as a coinjection marker to identify neurons that were successfully injected. The plasmid solution was centrifuged $(16,000 \times g)$ in nonheparinized hematocrit tubes for $20 \mathrm{~min}$ to remove particulates. Approximately $1.5 \mu \mathrm{l}$ of the plasmid solution was loaded into an injection pipette. Injection pipettes were pulled from fiber-filled capillary glass (1B120F-4; World Precision Instruments, Sarasota, FL) on a P-87 Flaming-Brown micropipette puller (Sutter Instrument Co., Novato, CA). The nucleus was microinjected with an Eppendorf (Madison, WI) 5242 microinjector and 5171 micromanipulator system with an injection pressure of $150-200 \mathrm{hPa}$ and an injection time of $0.3-0.4 \mathrm{sec}$. Neurons that were successfully intranuclearly microinjected appeared green under fluorescent optics (Nikon Diaphot 300 and B2A filter cube; Southern Micro Instruments, Atlanta, GA) from expression of the green fluorescent protein. Approximately 30-40 neurons per dish were microinjected and, of those, $<10 \%$ were successfully injected.

Electrophysiological recording and data analysis. $\mathrm{Ca}^{2+}$ currents from rat SCG neurons were recorded at room temperature $\left(22-26^{\circ} \mathrm{C}\right) 16-20 \mathrm{hr}$ after injection using the whole-cell variant of the patch-clamp technique (Hamill et al., 1981) with an Axopatch 200A patch-clamp amplifier (Axon Instruments, Foster City, CA). Patch electrode pipettes were pulled from borosilicate glass capillaries (Corning 7052; Garner Glass Co., Claremont, CA) on a P-87 Flaming-Brown micropipette puller (Sutter Instrument Co.). The patch electrodes were coated with Sylgard 184 (Dow Corning, Midland, MI) and fire-polished on a microforge (Narishige, Tokyo, Japan). Pipette resistances ranged from 1.8 to $3 \mathrm{M} \Omega$ when filled with the internal solution described below. The cell membrane capacitance and series resistance were electronically compensated to $>80 \%$. Whole-cell currents were low-pass filtered at $5 \mathrm{kHz}$ using the Bessel filter of the clamp amplifier.

Voltage-clamp protocols were generated with a Power Macintosh 8600/200 computer (Apple Computer, Cupertino, CA) equipped with a PCI-16 Host Interface card connected to an ITC-16 Data Acquisition Interface (Instrutech Corp., Port Washington, NY) using Pulse Control 5.0 XOPs (Richard J. Bookman, Jack D. Herrington, and Kenneth R. Newton, University of Miami, Miami, FL) with Igor software (WaveMetrics, Lake Oswego, OR). $\mathrm{Ca}^{2+}$ currents were elicited by voltage steps from a holding potential of $-80 \mathrm{mV}$ and digitized at $180 \mu \mathrm{sec}$ per point. A double pulse protocol consisting of two $25 \mathrm{msec}$ steps to $+5 \mathrm{mV}$ was used to elicit $\mathrm{Ca}^{2+}$ currents. The first step to $+5 \mathrm{mV}$ elicited the control $\mathrm{Ca}^{2+}$ current. The second step to $+5 \mathrm{mV}$ was preceded by a $50 \mathrm{msec}$ step to $+80 \mathrm{mV}$. The current elicited by the second voltage step to $+5 \mathrm{mV}$ is facilitated compared to the control current elicited by the first voltage step. Current amplitudes were measured isochronally $10 \mathrm{msec}$ after the voltage step. Figures were generated using Igor (WaveMetrics) and Excel (Microsoft, Redmond, WA) with final preparation in Canvas (Deneba Systems, Miami, FL). Results are presented as means \pm SEM where appropriate. Statistical significance was determined by Student's $t$ test. The differences were considered significant at $p<0.05$.
Solutions. To isolate $\mathrm{Ca}^{2+}$ currents for whole-cell recording, cells were bathed in an external solution that contained (in mM): 140 tetraethylammonium methanesulfonate, $10 \mathrm{HEPES}, 15$ glucose, $10 \mathrm{CaCl}_{2}$, and 0.0001 tetrodotoxin (Calbiochem, La Jolla, CA), pH 7.4 (adjusted with methanesulfonic acid). The intracellular solution consisted of (in mM): 120 $N$-methyl-D-glucamine, 20 tetraethylammonium chloride, $10 \mathrm{HEPES}, 11$ EGTA, $1 \mathrm{CaCl}_{2}, 4 \mathrm{MgATP}, 0.1 \mathrm{Na}_{2} \mathrm{GTP}$, and 14 phosphocreatine, $\mathrm{pH}$ 7.2 (adjusted with methanesulfonic acid).

Two different techniques were used to apply drugs to the patched neurons during the course of this study. Drug solutions were applied from a macropipette (20-30 $\mu \mathrm{m}$ tip diameter; type N51A glass; Garner Glass Co.) lowered into the bath. To terminate drug application, the macropipette was removed from the bath, which was superfused at $1 \mathrm{ml} / \mathrm{min}$. To apply multiple drugs, the SF-77B Perfusion Fast-Step device (Warner Instrument Corporation, Hamden, CT) was used. This device allowed for fast switching between control or drug-containing solutions. All compounds were diluted into the external solution from concentrated stock solutions on the day of the experiment. Stock solutions of $10 \mathrm{~mm}$ WIN 55,212-2 mesylate (Research Biochemicals International, Natick, MA) and SR 141716A (Sanofi Recherche, Montpellier, France) were prepared in dimethylsulfoxide. WIN 55,212-2 and SR 141716A were diluted into the external solution and briefly sonicated to facilitate dispersion. The final concentration of dimethylsulfoxide was $<0.01 \%$, which had no effect on the $\mathrm{Ca}^{2+}$ current. Stock solutions of $10 \mathrm{~mm}$ norepinephrine (Research Biochemicals International), 1 mм (D-Trp ${ }^{8}$ )somatostatin-14 (Bachem California Inc., Torrance, CA), 1 mm vasoactive intestinal polypeptide (VIP) (Bachem California Inc.), and $10 \mathrm{~mm}$ L-glutamate (Sigma, St. Louis, MO) were made in water. All stock solutions were stored at -20 or $-50^{\circ} \mathrm{C}$.

\section{RESULTS}

\section{CB1 cannabinoid receptor expression abolished the ability of norepinephrine and somatostatin to inhibit voltage-dependent $\mathrm{Ca}^{2+}$ currents in SCG neurons}

If expression of $\mathrm{hCB} 1$ receptors leads to sequestration of G-proteins from a common pool, then other G-protein-coupled receptors would be unable to signal because of a lack of G-proteins with which to couple. Both $\alpha_{2}$-adrenergic and somatostatin receptors have been shown to couple to pertussis toxinsensitive G-proteins and to inhibit voltage-dependent $\mathrm{Ca}^{2+}$ currents in SCG neurons (Ikeda and Schofield, 1989; Schofield, 1990, 1991). We predicted that expression of hCB1 receptors in SCG neurons would abolish the ability of norepinephrine and somatostatin to inhibit $\mathrm{Ca}^{2+}$ currents.

Whole-cell $\mathrm{Ca}^{2+}$ currents were recorded from control, uninjected SCG neurons. Figure $1 A$ illustrates the time course of the effect of the cannabinoid receptor agonist WIN 55,212-2 and NE on both control and facilitated $\mathrm{Ca}^{2+}$ currents elicited by a double pulse protocol (Fig. $1 B)$. Application of NE $(10 \mu \mathrm{M})$ inhibited both control and facilitated $\mathrm{Ca}^{2+}$ currents (Fig. $1 A, B$ ). Application of WIN 55,212-2 had no effect on the $\mathrm{Ca}^{2+}$ current in this uninjected SCG neuron. Rat SCG neurons have been shown to contain CB1 mRNA as detected by the reverse transcription-PCR (Ishac et al., 1996). However, our experiments could not detect cannabinoid receptor modulation of $\mathrm{Ca}^{2+}$ currents from the soma of rat SCG neurons in culture. Because cannabinoid agonists inhibited the release of noradrenaline from sympathetic nerves innervating isolated rat atria (Ishac et al., 1996), CB1 receptors may be specifically localized in SCG neuronal terminals. Terminal localization of CB1 receptors has recently been shown in GABAergic hippocampal interneurons (Katona et al., 1999).

To express cannabinoid receptors we microinjected $100 \mathrm{ng} / \mu \mathrm{l}$ hCB1 cannabinoid receptor cDNA directly into the nucleus of SCG neurons. Application of the cannabinoid receptor agonist WIN 55,212-2 inhibited the $\mathrm{Ca}^{2+}$ current in this SCG neuron injected with hCB1 cDNA (Fig. 1C,D). WIN 55,212-2 inhibited 

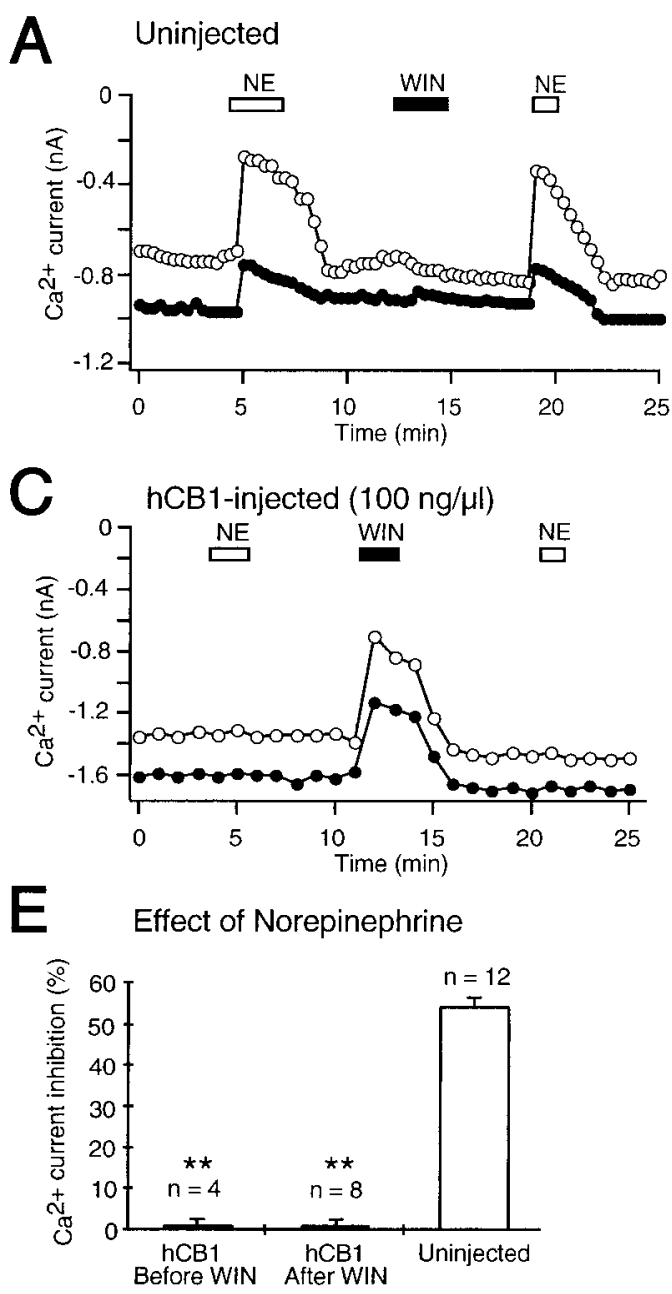

B

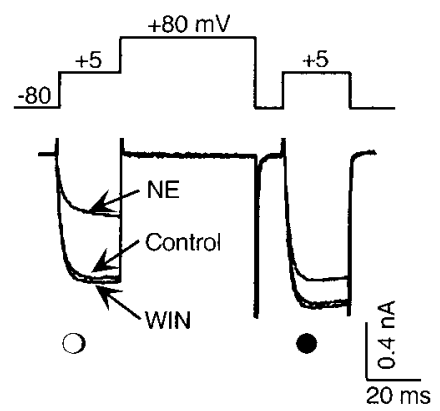

D
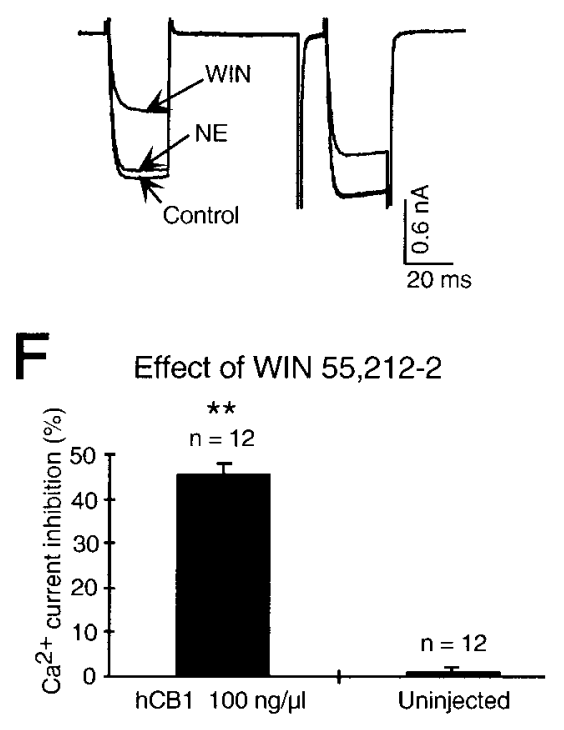

Figure 1. Expression of hCB1 cannabinoid receptors abolished inhibition of $\mathrm{Ca}^{2+}$ currents by norepinephrine $(N E)$ in SCG neurons. $A$, A double pulse protocol $(B$, inset) was used to elicit control (open circle) and facilitated (filled circle) $\mathrm{Ca}^{2+}$ currents in a control, uninjected SCG neuron. The double pulse protocol was repeated every $10 \mathrm{sec}$, and the current amplitudes were plotted over the time course of the experiment. Application of $10 \mu \mathrm{M}$ norepinephrine (NE, open bar) reversibly decreased the $\mathrm{Ca}^{2+}$ current. A subsequent application of $1 \mu \mathrm{M}$ WIN $55,212-2$, the cannabinoid receptor agonist (WIN, filled bar), had no effect. A second application of norepinephrine again decreased the $\mathrm{Ca}^{2+}$ current. $B$, Superimposed current traces elicited by the double pulse protocol (top) from the same cell as shown in $A$ in the absence (Control) and presence of norepinephrine $(N E)$ and WIN 55,212-2 $(W I N)$. The first voltage step to $+5 \mathrm{mV}$ elicited the control $\mathrm{Ca}^{2+}$ current (open circle), and the second step to $+5 \mathrm{mV}$, which was preceded by a $+80 \mathrm{mV}$ step, elicited the facilitated (filled circle) $\mathrm{Ca}^{2+}$ current. $C$, In an SCG neuron previously microinjected with $100 \mathrm{ng} / \mu \mathrm{l} \mathrm{hCB} 1$, cannabinoid receptor cDNA application of $10 \mu \mathrm{M}$ norepinephrine (NE, open bar) had no effect on the $\mathrm{Ca}^{2+}$ current. A subsequent application of $1 \mu \mathrm{M}$ WIN 55,212-2 (WIN, filled bar) inhibited the $\mathrm{Ca}^{2+}$ current, which slowly recovered after washout. A second application of norepinephrine also had no effect on the $\mathrm{Ca}^{2+}$ current. $D$, Superimposed current traces from the same cell as shown in $C$ in the absence (Control) and presence of WIN 55,212-2 (WIN) and norepinephrine (NE). $E$, Bar graph of control $\mathrm{Ca}^{2+}$ current inhibition by $10 \mu \mathrm{M}$ norepinephrine in uninjected SCG neurons (Uninjected) and in SCG

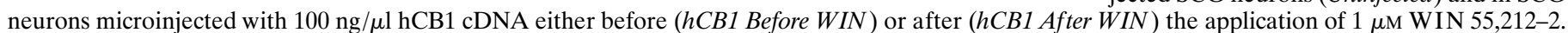

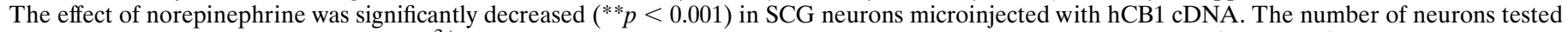

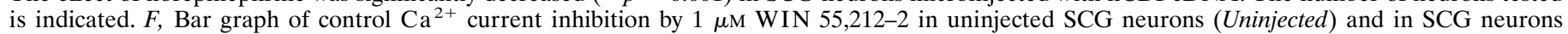

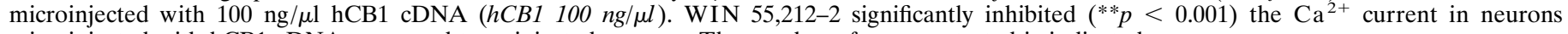
microinjected with hCB1 cDNA compared to uninjected neurons. The number of neurons tested is indicated.

the $\mathrm{Ca}^{2+}$ current $45.5 \pm 2.4 \%(n=12 ; p<0.001)$ in SCG neurons microinjected with hCB1 receptor cDNA compared with $1.1 \pm 0.6 \%(n=12)$ in uninjected neurons (Fig. $1 F)$. Thus, microinjection of plasmids directly into the nucleus leads to expression of hCB1 receptors.

To determine whether expression of hCB1 receptors could abolish signaling by $\alpha_{2}$-adrenergic receptors, SCG neurons microinjected with hCB1 cDNA were challenged with NE. NE $(10 \mu \mathrm{M})$ had no effect on the $\mathrm{Ca}^{2+}$ current in the SCG neuron microinjected with $100 \mathrm{ng} / \mu \mathrm{l}$ hCB1 cDNA (Fig. $1 C, D$ ). In summary, NE $(10 \mu \mathrm{M})$ decreased the $\mathrm{Ca}^{2+}$ current $54.7 \pm 1.6 \%(n=12)$ in uninjected neurons (Fig. $1 E$ ). In contrast, NE had no effect on the $\mathrm{Ca}^{2+}$ current in neurons microinjected with $100 \mathrm{ng} / \mu \mathrm{l} \mathrm{hCB} 1$ cDNA (Fig. $1 E$ ) either before $(0.7 \pm 1.2 \% ; n=4 ; p<0.001)$ or after $(0.8 \pm 1.3 \% ; n=8 ; p<0.001)$ the application of WIN $55,212-2$.

The effect of somatostatin was also inhibited by expression of hCB1 receptors. Figure $2 A$ illustrates the time course of the effect of SOM and WIN 55,212-2 on $\mathrm{Ca}^{2+}$ currents in a control, uninjected SCG neuron. Application of SOM $(0.1 \mu \mathrm{M})$ inhibited the $\mathrm{Ca}^{2+}$ current, but WIN 55,212-2 (1 $\left.\mu \mathrm{M}\right)$ had no effect (Fig. $2 A, B)$. In SCG neurons microinjected with $100 \mathrm{ng} / \mu \mathrm{l} \mathrm{hCB} 1$
cDNA, WIN 55,212-2 inhibited the $\mathrm{Ca}^{2+}$ current, but SOM had no effect (Fig. $2 C, D)$. SOM $(0.1 \mu \mathrm{M})$ inhibited the $\mathrm{Ca}^{2+}$ current in control, uninjected neurons $53.9 \pm 1.3 \%(n=12)$ (Fig. $2 E)$. In contrast, SOM had no significant effect in neurons microinjected with $100 \mathrm{ng} / \mu \mathrm{l}$ hCB1 cDNA either before $(2.0 \pm 0.4 \% ; n=6 ; p<$ $0.001)$ or after $(0.9 \pm 0.8 \% ; n=6 ; p<0.001)$ the application of WIN 55,212-2. The hCB1 receptor was expressed in these neurons because WIN 55,212-2 inhibited the $\mathrm{Ca}^{2+}$ current $43.5 \pm$ $2.0 \%(n=12 ; p<0.001)$ compared to uninjected neurons $(0.1 \pm$ $0.5 \% ; n=12$ ) (Fig. $2 F$ ). These results demonstrate that expression of the hCB1 receptor abolished the signaling by endogenous receptors for both NE and SOM in SCG neurons.

\section{Inhibition of norepinephrine and somatostatin receptor signaling by expression of the hCB1 receptor depended on the concentration of hCB1 cDNA microinjected}

To determine whether NE and SOM signal disruption depended on the abundance of hCB1 receptors, different concentrations of hCB1 cDNA were microinjected. In control, uninjected neurons, $\mathrm{NE}(10 \mu \mathrm{M})$ inhibited the $\mathrm{Ca}^{2+}$ current $54.0 \pm 2.6 \%(n=21)$ 
Figure 2. Expression of hCB1 cannabinoid receptors abolished inhibition of the $\mathrm{Ca}^{2+}$ current by somatostatin (SOM) in SCG neurons. $A$, Application of $0.1 \mu \mathrm{M}$ somatostatin (SOM, hatched bar) reversibly decreased the $\mathrm{Ca}^{2+}$ current in an uninjected SCG neuron. A subsequent application of $1 \mu \mathrm{M}$ WIN 55,212-2 ( filled bar) had no effect. A second application of somatostatin again decreased the $\mathrm{Ca}^{2+}$ current. $B$, Superimposed current traces from the same cell as shown in $A$ in the absence (Control $)$ and presence of somatostatin $(S O M)$ and WIN 55,212-2 (WIN). C, In an SCG neuron previously microinjected with $100 \mathrm{ng} / \mu \mathrm{l} \mathrm{hCB} 1$ cannabinoid receptor cDNA, application of 0.1 $\mu \mathrm{M}$ somatostatin (hatched bar) had no effect on the $\mathrm{Ca}^{2+}$ current. A subsequent application of $1 \mu \mathrm{M}$ WIN 55,212-2 ( filled bar) inhibited the $\mathrm{Ca}^{2+}$ current. A second application of somatostatin also had no effect on the $\mathrm{Ca}^{2+}$ current. $D$, Superimposed current traces from the same cell as shown in $C$ in the absence (Control) and presence of WIN 55,212-2 (WIN) and somatostatin $(S O M)$. E, Bar graph of control $\mathrm{Ca}^{2+}$ current inhibition by somatostatin in uninjected SCG neurons (Uninjected) and in SCG neurons microinjected with $100 \mathrm{ng} / \mu \mathrm{l} \mathrm{hCB} 1$ cDNA either before ( $h C B 1$ Before WIN) or after ( $h C B 1$ After WIN) the application of 1 $\mu \mathrm{M}$ WIN 55,212-2. The effect of somatostatin was significantly decreased $(* * p 0.001)$ in SCG neurons microinjected with hCB1 cDNA. The number of neurons tested is indicated. $F$, Bar graph of control $\mathrm{Ca}^{2+}$ current inhibition by $1 \mu \mathrm{M}$ WIN 55,212-2 in uninjected SCG neurons (Uninjected) and in SCG neurons microinjected with $100 \mathrm{ng} / \mu \mathrm{l}$ hCB1 cDNA (hCB1 100 $n g / \mu l)$. The cannabinoid receptor agonist WIN $55,212-2$ significantly inhibited $\left({ }^{* *} p<0.001\right)$ the $\mathrm{Ca}^{2+}$ current in neurons microinjected with hCB1 cDNA when compared to uninjected neurons. The number of neurons tested is indicated.
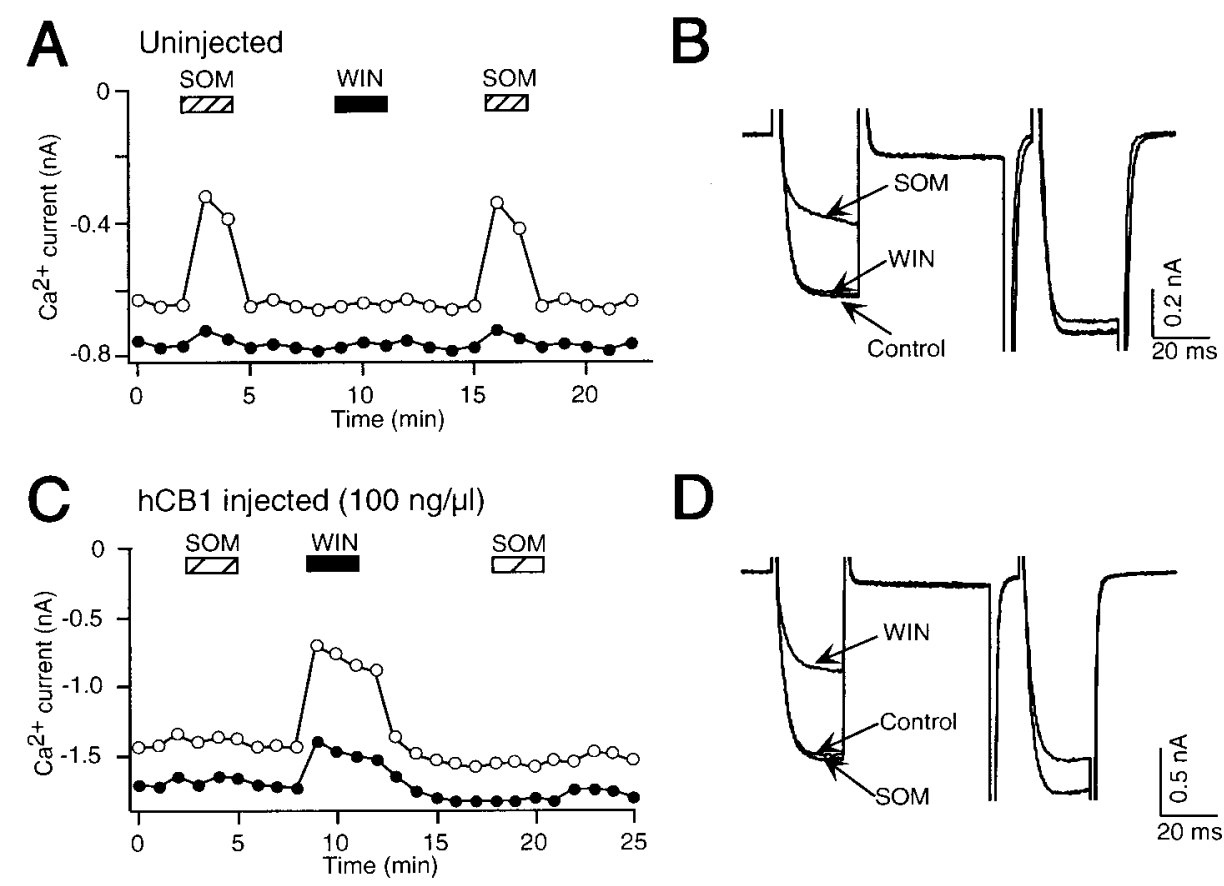

\section{D}
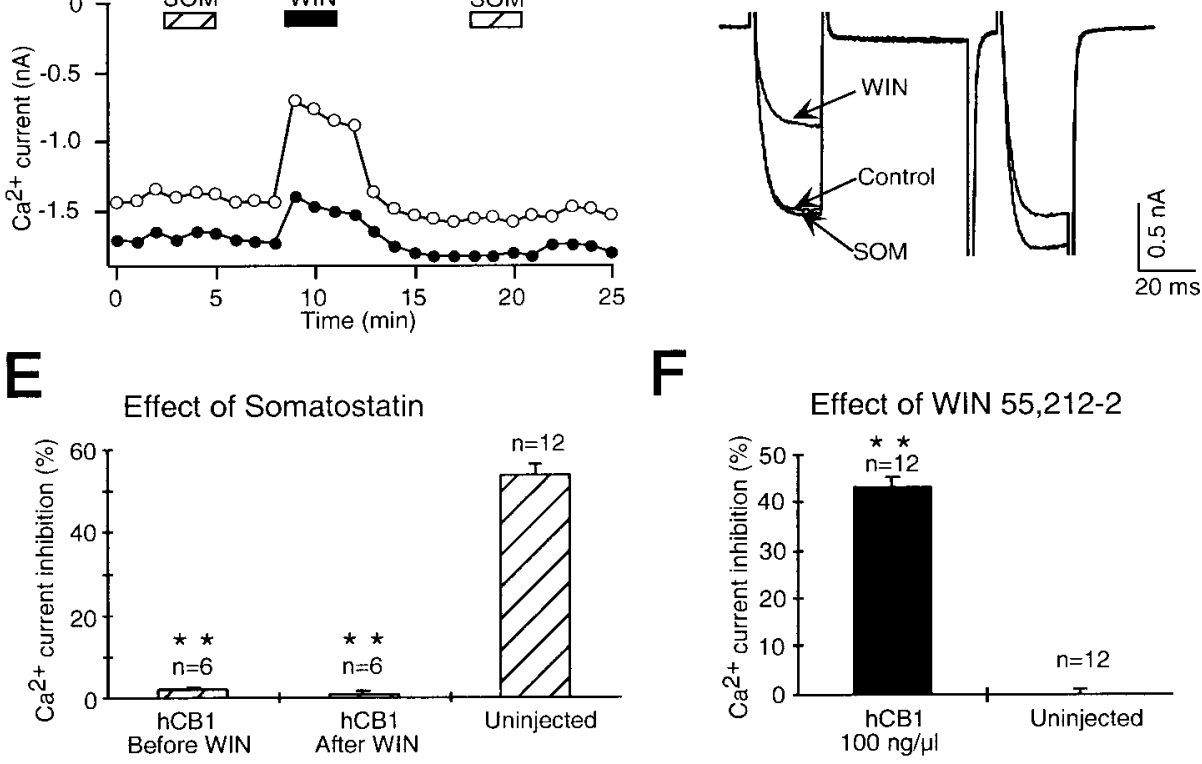

Effect of WIN 55,212-2

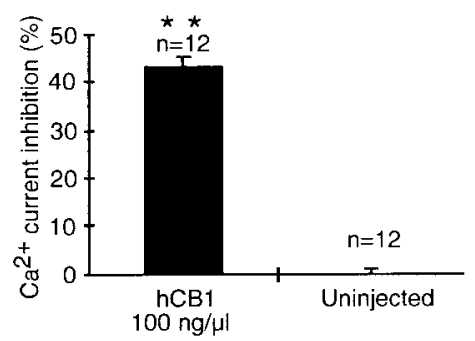

(Fig. 3). Microinjection of $10 \mathrm{ng} / \mu \mathrm{l}$ of hCB1 cDNA had no effect on the inhibition of the $\mathrm{Ca}^{2+}$ current by NE $(50.4 \pm 4.3 \% ; n=$ $3)$. The effect of NE was significantly decreased $(34.1 \pm 4.9 \% ; n=$ $6 ; p<0.05)$ in SCG neurons microinjected with $50 \mathrm{ng} / \mu \mathrm{l}$ of hCB1 cDNA. The response to NE was completely abolished in neurons microinjected with $100 \mathrm{ng} / \mu \mathrm{l} \mathrm{hCB1} \mathrm{cDNA}(0.8 \pm 1.3 \%$; $n=12$; $p<0.001)$.

SOM $(0.1 \mu \mathrm{M})$ inhibited the $\mathrm{Ca}^{2+}$ current $53.5 \pm 1.5 \%(n=$ 16) in uninjected neurons (Fig. 3). In SCG neurons microinjected with $50 \mathrm{ng} / \mu \mathrm{l} \mathrm{hCB1} \mathrm{cDNA}$, SOM inhibited the $\mathrm{Ca}^{2+}$ current $34.7 \pm 3.9 \%(n=4 ; p<0.05)$. The response to SOM was abolished in neurons microinjected with $100 \mathrm{ng} / \mu \mathrm{l}$ hCB1 cDNA $(1.5 \pm 0.6 \% ; n=12 ; p<0.001)$.

All neurons microinjected with hCB1 cDNA were checked for hCB1 receptor expression by measuring the effect of WIN 55,212-2 on the $\mathrm{Ca}^{2+}$ current. Receptor expression was low in SCG neurons microinjected with $10 \mathrm{ng} / \mu \mathrm{l} \mathrm{hCB1} \mathrm{cDNA}$, as indicated by a $12.9 \pm 1.6 \%(n=3)$ decrease in the $\mathrm{Ca}^{2+}$ current in response to $1 \mu \mathrm{M}$ WIN 55,212-2. The effect of WIN 55,212-2 was similar in SCG neurons microinjected with 50 or $100 \mathrm{ng} / \mu \mathrm{l} \mathrm{hCB} 1$ cDNA. WIN 55,212-2 decreased the $\mathrm{Ca}^{2+}$ current $44.7 \pm 1.3 \%$ $(n=10)$ in neurons microinjected with $50 \mathrm{ng} / \mu \mathrm{lhCB} 1 \mathrm{cDNA}$ and $44.5 \pm 2.2 \%(n=24)$ in neurons microinjected with $100 \mathrm{ng} / \mu \mathrm{l}$ hCB1 cDNA. WIN 55,212-2 had no effect $(0.8 \pm 0.6 \% ; n=34)$ in uninjected neurons.

\section{Heterologous expression of the mGluR2 metabotropic glutamate receptor had no effect on adrenergic and somatostatin signaling}

To determine whether the block of adrenergic and somatostatin signaling is specific to expression of hCB1 receptors, SCG neurons were microinjected with mGluR2 metabotropic glutamate receptor cDNA. Heterologous expression of mGluR2 receptors has previously been shown to inhibit $\mathrm{Ca}^{2+}$ currents in SCG neurons by coupling to pertussis toxin-sensitive G-proteins (Ikeda et al., 1995).

In control, uninjected neurons L-glutamate had no effect on the $\mathrm{Ca}^{2+}$ current $(1.6 \pm 1.3 \% ; n=18)$, confirming the absence of endogenous metabotropic glutamate receptors (Fig. $4 E$ ). In an SCG neuron microinjected with $100 \mathrm{ng} / \mu \mathrm{l} \mathrm{mGluR2} \mathrm{cDNA}, \mathrm{NE}$ (Fig. $4 A, B$ ) reversibly reduced the $\mathrm{Ca}^{2+}$ current. A subsequent application of L-glutamate $(100 \mu \mathrm{M})$ also reversibly decreased the $\mathrm{Ca}^{2+}$ current demonstrating mGluR2 receptor expression. A second application of NE had an effect similar to the first application. In summary, NE $(10 \mu \mathrm{M})$ reduced the $\mathrm{Ca}^{2+}$ current $48.0 \pm 2.2 \%(n=8)$ in neurons microinjected with $100 \mathrm{ng} / \mu \mathrm{l}$ mGluR2 cDNA (Fig. 4E), which was no different from the effect of $\mathrm{NE}(49.9 \pm 1.9 \% ; n=18)$ in uninjected neurons. We also tested the effect of NE in neurons microinjected with $50 \mathrm{ng} / \mu \mathrm{l}$ mGluR2 cDNA. In these neurons NE inhibited the $\mathrm{Ca}^{2+}$ current $47.2 \pm 0.9 \%(n=5)$. L-glutamate decreased the $\mathrm{Ca}^{2+}$ current 


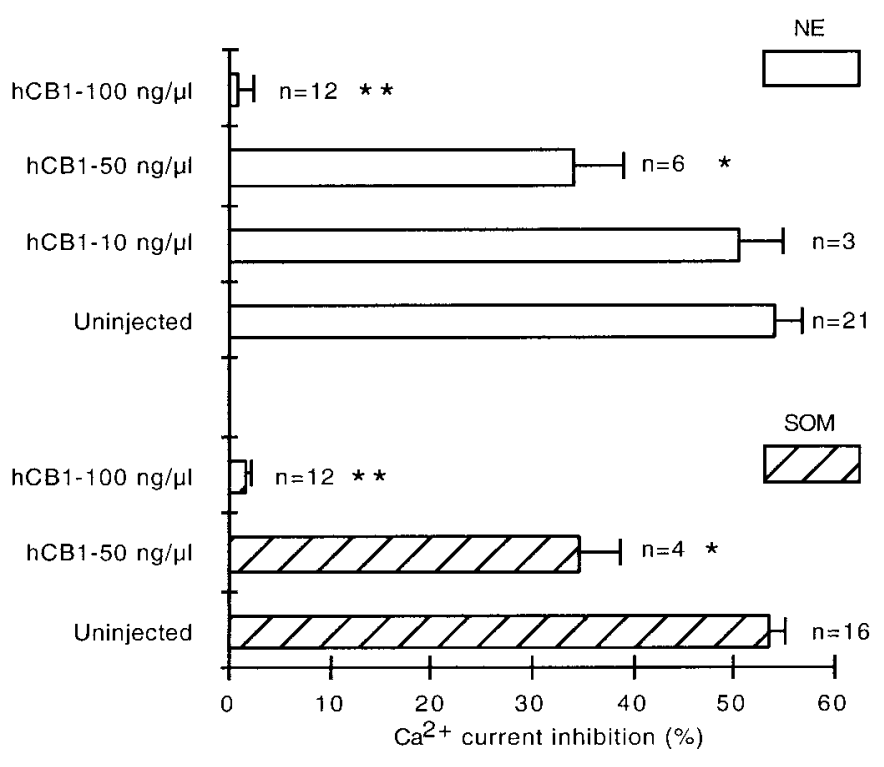

Figure 3. Dose-dependent effect of hCB1 cDNA on signaling by receptors for norepinephrine and somatostatin. Bar graph of control $\mathrm{Ca}^{2+}$ current inhibition by norepinephrine ( $N E$, open bars) and somatostatin (SOM, diagonal bars) in uninjected SCG neurons (Uninjected) and in neurons microinjected with 10,50 , and $100 \mathrm{ng} / \mu 1 \mathrm{hCB} 1 \mathrm{cDNA}(h C B 1)$. Microinjection of $50 \mathrm{ng} / \mu \mathrm{l}$ hCB1 cDNA significantly reduced $\left({ }^{*} p<0.05\right)$ the inhibition of the $\mathrm{Ca}^{2+}$ current by both norepinephrine and somatostatin. Microinjection of $100 \mathrm{ng} / \mu \mathrm{l} \mathrm{hCB} 1 \mathrm{cDNA}$ abolished $\left({ }^{* *} p<0.001\right)$ the inhibition of the $\mathrm{Ca}^{2+}$ current by both norepinephrine and somatostatin. The number of neurons tested is indicated.

$55.7 \pm 2.4 \%(n=8)$ in neurons microinjected with $100 \mathrm{ng} / \mu \mathrm{l}$ mGluR2 cDNA and $54.5 \pm 2.9 \%(n=5)$ in neurons microinjected with $50 \mathrm{ng} / \mu \mathrm{l} \mathrm{mGluR2} \mathrm{cDNA}$, demonstrating mGluR2 receptor expression at both cDNA concentrations (Fig. $4 E$ ).

There was also no difference in the response to SOM in control, uninjected neurons compared to those microinjected with mGluR2 cDNA. In uninjected neurons, SOM $(0.1 \mu \mathrm{M})$ reduced the $\mathrm{Ca}^{2+}$ current $51.4 \pm 0.1 \%(n=11)$. In neurons microinjected with 50 and $100 \mathrm{ng} / \mu \mathrm{lmGluR2} \mathrm{cDNA}$, SOM inhibited the $\mathrm{Ca}^{2+}$ current $50.0 \pm 1.4 \%(n=5)$ and $50.5 \pm 1.1 \%(n=6)$, respectively (data not shown).

As a further control, mGluR2 cDNA was microinjected at twice the concentration of $\mathrm{hCB} 1$ receptor cDNA. In neurons microinjected with $200 \mathrm{ng} / \mu \mathrm{l} \mathrm{mGluR2} \mathrm{cDNA}, \mathrm{NE}$ decreased the $\mathrm{Ca}^{2+}$ current $43.5 \pm 4.6 \%(n=5)$ (Fig. $\left.4 E\right)$, which was no different from the NE-induced decrease of $48.8 \pm 1.3 \%(n=5)$ in uninjected neurons recorded on the same day. L-glutamate (100 $\mu \mathrm{M})$ inhibited the $\mathrm{Ca}^{2+}$ current $55.6 \pm 2.0 \%(n=5)$ in the neurons microinjected with $200 \mathrm{ng} / \mu \mathrm{l} \mathrm{mGluR2}$ cDNA. Thus, heterologous expression of the mGluR2 metabotropic glutamate receptor had no effect on the signaling of endogenous $\mathrm{NE}$ and SOM receptors.

\section{Heterologous expression of the hCB1 receptor had no effect on the signaling of $a \mathrm{G}_{\mathrm{s}}$-coupled receptor}

To determine if expression of hCB1 receptors specifically disrupted signaling of pertussis toxin-sensitive G-protein-coupled receptors we looked for disruption of signaling by an endogenous $\mathrm{G}_{\mathrm{s}}$ coupled receptor. VIP acts on endogenous receptors coupled to $\mathrm{G}_{\mathrm{s}}$ in SCG neurons to inhibit the $\mathrm{Ca}^{2+}$ current ( $\mathrm{Zhu}$ and Ikeda, 1994). In an SCG neuron microinjected with $100 \mathrm{ng} / \mu \mathrm{l}$ hCB1 cDNA, WIN 55,212-2 (Fig. 4C,D) reversibly reduced the
$\mathrm{Ca}^{2+}$ current, demonstrating hCB1 receptor expression. A subsequent application of VIP $(10 \mu \mathrm{M})$ also reversibly decreased the $\mathrm{Ca}^{2+}$ current. A second application of WIN 55,212-2 had an effect similar to the first application. In neurons microinjected with hCB1 cDNA, WIN 55,212-2 reduced the $\mathrm{Ca}^{2+}$ current $43.6 \pm 1.7 \%(n=4)$, and VIP decreased the $\mathrm{Ca}^{2+}$ current $53.0 \pm$ $1.1 \%(n=4)$ (Fig. $4 E)$. In uninjected neurons, the effect of VIP was similar. VIP inhibited the $\mathrm{Ca}^{2+}$ current $55.2 \pm 2.0 \%(n=5)$. These results demonstrate that hCB1 receptor expression had no effect on signaling by an endogenous receptor coupled to the pertussis toxin-insensitive $\mathrm{G}$-protein $\mathrm{G}_{\mathrm{s}}$.

\section{The cannabinoid receptor inverse agonist SR 141716A trapped the hCB1 in an inactive state and sequestered G-proteins from a common pool}

In SCG neurons microinjected with hCB1 cDNA, the cannabinoid receptor inverse agonist SR $141716 \mathrm{~A}$ increased the $\mathrm{Ca}^{2+}$ current, an effect opposite that of the cannabinoid agonist WIN 55,212-2 (Pan et al., 1998). An increase in the $\mathrm{Ca}^{2+}$ current occurred as SR 141716A relieved a tonic inhibition of the $\mathrm{Ca}^{2+}$ current caused by tonically active hCB1 receptors. Because an inverse agonist has higher affinity for the inactive state of the receptor, it will shift the balance to the inactive state and reverse the effects of a tonically active receptor. If SR 141716A can trap the hCB1 receptor in its inactive state together with its associated G-protein as proposed by Bouaboula et al. (1997), then this entrapment could sequester a common pool of G-proteins. To test whether G-proteins associated with receptors for NE or SOM could be sequestered by the hCB1 receptor trapped in its inactive state by the inverse agonist SR 141716A, experiments were performed to test $\mathrm{NE}$ and SOM both before and after application of SR 141716A. Figure $5 A$ shows the time course of the effect of NE and SR $141716 \mathrm{~A}$ on the $\mathrm{Ca}^{2+}$ current in a control, uninjected neuron. NE $(10 \mu \mathrm{M})$ reduced the $\mathrm{Ca}^{2+}$ current, but SR 141716A (1 $\mu \mathrm{M})$ had no effect. A second application of NE inhibited the $\mathrm{Ca}^{2+}$ current. Neurons microinjected with $50 \mathrm{ng} / \mu \mathrm{l} \mathrm{hCB} 1 \mathrm{cDNA}$ were tested with $\mathrm{NE}$ before and after application of the cannabinoid receptor inverse agonist SR 141716A. The first application of $\mathrm{NE}$ reversibly reduced the $\mathrm{Ca}^{2+}$ current. Application of SR 141716A increased the $\mathrm{Ca}^{2+}$ current, which remained elevated even after superfusion with external solution. A subsequent application of $\mathrm{NE}$ had no effect on the $\mathrm{Ca}^{2+}$ current. In SCG neurons microinjected with $50 \mathrm{ng} / \mu \mathrm{l} \mathrm{hCB1} \mathrm{cDNA}$, the first application of $\mathrm{NE}$ reduced the $\mathrm{Ca}^{2+}$ current $30.2 \pm 2.6 \%(n=4)$ (Fig. 5C), and SR 141716A increased the $\mathrm{Ca}^{2+}$ current $44.4 \pm$ $0.9 \%(n=4)$. In contrast, NE applied after SR 141716A had no significant effect on the $\mathrm{Ca}^{2+}$ current $(1.8 \pm 0.6 \% ; n=4 ; p<$ $0.001)$. In uninjected neurons, the first application of $\mathrm{NE}$ blocked the $\mathrm{Ca}^{2+}$ current $51.3 \pm 1.3 \%(n=5)$ (Fig. 5C), SR $141716 \mathrm{~A}$ had no effect $(0.4 \pm 0.6 \% ; n=5)$, and the second application of $\mathrm{NE}$ inhibited the $\mathrm{Ca}^{2+}$ current $50.9 \pm 1.7 \%(n=5)$. Similar results were obtained for SOM in SCG neurons microinjected with 50 $\mathrm{ng} / \mu \mathrm{l}$ hCB1 cDNA. The first application of SOM $(0.1 \mu \mathrm{M})$ reduced the $\mathrm{Ca}^{2+}$ current $35.0 \pm 2.5 \%(n=6)$, SR $141716 \mathrm{~A}$ increased the $\mathrm{Ca}^{2+}$ current $45.3 \pm 0.7 \%(n=6)$, and the second application of SOM had no effect on the $\mathrm{Ca}^{2+}$ current $(1.7 \pm$ $0.2 \% ; n=6 ; p<0.001)$. In control, uninjected neurons the first application of SOM reduced the $\mathrm{Ca}^{2+}$ current $54.2 \pm 1.0 \%(n=$ $6)$, SR $141716 \mathrm{~A}$ had no effect on the $\mathrm{Ca}^{2+}$ current $(0.7 \pm 0.9 \%$; $n=6)$, and the second application of SOM inhibited the $\mathrm{Ca}^{2+}$ current $51.2 \pm 1.3 \%(n=6)$ (data not shown). These results indicate that the inverse agonist-trapped inactive state of the 
Figure 4. The hCB1 cannabinoid receptor specifically disrupts signaling by $\mathrm{G}_{\mathrm{i} / \mathrm{o}^{-}}$ coupled receptors and is not mimicked by expression of the mGluR2 metabotropic glutamate receptor. $A$, Expression of the mGluR2 metabotropic glutamate receptor, a pertussis toxin-sensitive G-protein-coupled receptor, did not alter the signaling of the receptor for norepinephrine. Application of $10 \mu \mathrm{M}$ norepinephrine (NE, open bar) inhibited the $\mathrm{Ca}^{2+}$ current in an SCG neuron microinjected with mGluR2 metabotropic glutamate receptor cDNA $(100 \mathrm{ng} / \mu \mathrm{l})$. A subsequent application of $100 \mu \mathrm{M}$ L-glutamate ( $L$-Glu, filled bar) reversibly inhibited the $\mathrm{Ca}^{2+}$ current. A second application of norepinephrine also inhibited the $\mathrm{Ca}^{2+}$ current. $B$, Superimposed current traces from the same cell as shown in $A$ in the absence (Control) and presence of L-glutamate $(L-G l u)$ and norepinephrine $(N E)$. C, Expression of the hCB1 cannabinoid receptor failed to affect signaling through the $\mathrm{G}_{\mathrm{s}}$-coupled receptor for vasoactive intestinal polypeptide $(V I P)$. Application of $1 \mu \mathrm{M}$ WIN 55,212-2 (WIN, filled bar) inhibited the $\mathrm{Ca}^{2+}$ current in an SCG neuron microinjected with hCB1 cDNA (100 $\mathrm{ng} / \mu \mathrm{l})$. A subsequent application of $10 \mu \mathrm{M}$ VIP (hatched bar) reversibly inhibited the $\mathrm{Ca}^{2+}$ current. A second application of WIN $55,212-2$ again inhibited the $\mathrm{Ca}^{2+}$ current. $D$, Superimposed current traces from the same cell as shown in $C$ in the absence (Control) and presence of $10 \mu \mathrm{M}$ VIP (VIP) and $1 \mu \mathrm{M}$ WIN 55,212-2 (WIN). E, Bar graph of the inhibition of the control $\mathrm{Ca}^{2+}$ current by L-glutamate ( filled bars), norepinephrine (open bars), and VIP (hatched bars) in uninjected SCG neurons (Uninjected), in neurons microinjected with 50 , 100 , or $200 \mathrm{ng} / \mu 1 \mathrm{mGluR} 2 \mathrm{cDNA}$ (mGluR2) and in neurons microinjected with hCB1 cDNA (hCB1). Uninjected neurons have no endogenous mGluR2 receptors and L-glutamate had no effect on the $\mathrm{Ca}^{2+}$ current (filled bar, Uninjected). In contrast, in neurons microinjected with 50,100, or 200 ng/ $\mu 1$ mGluR2 cDNA L-glutamate significantly inhibited the $\mathrm{Ca}^{2+}$ current $\left({ }^{* *} p<\right.$ 0.001 , filled bars, $m$ GluR2). The effect of norepinephrine on the $\mathrm{Ca}^{2+}$ current was no different in neurons microinjected with 50 , 100 , or $200 \mathrm{ng} / \mu \mathrm{l} \mathrm{mGluR2}$ cDNA (open bars,

$m$ GluR2) than in uninjected neurons (open bar, Uninjected). VIP inhibited the $\mathrm{Ca}^{2+}$ current in both uninjected neurons (hatched bar, Uninjected) and in neurons microinjected with $100 \mathrm{ng} / \mu \mathrm{l}$ hCB1 cDNA (hatched bar, hCB1 $100 \mathrm{ng} / \mu \mathrm{l}$ ). The number of neurons tested is indicated.

hCB1 receptor could sequester G-proteins that were previously available to couple to $\alpha_{2}$-adrenergic and somatostatin receptors.

\section{The abundance of tonically active hCB1 receptors depended on the concentration of hCB1 cDNA microinjected}

Disruption of NE and SOM signaling by expression of hCB1 receptors depended on the concentration of hCB1 cDNA microinjected. In neurons microinjected with $100 \mathrm{ng} / \mu \mathrm{l} \mathrm{hCB1} \mathrm{cDNA}$, signaling by $\mathrm{NE}$ and $\mathrm{SOM}$ was abolished, but in neurons microinjected with $50 \mathrm{ng} / \mu \mathrm{l} \mathrm{hCB} 1 \mathrm{cDNA}$, signaling by $\mathrm{NE}$ and SOM was reduced (Fig. 3). We hypothesized that the tonically active state of the hCB1 receptor was responsible for sequestering G-proteins and abolishing the effect of NE and SOM. If this hypothesis is correct, then there should be more tonically active receptors in neurons microinjected with $100 \mathrm{ng} / \mu \mathrm{l} \mathrm{hCB} 1 \mathrm{cDNA}$, and the effect of the inverse agonist SR 141716A should be greater than in neurons microinjected with $50 \mathrm{ng} / \mu \mathrm{l} \mathrm{hCB} 1 \mathrm{cDNA}$. In neurons microinjected with $50 \mathrm{ng} / \mu \mathrm{l}$ hCB1 cDNA, SR 141716A $(1 \mu \mathrm{M})$ increased the $\mathrm{Ca}^{2+}$ current $44.9 \pm 0.8 \%(n=10)$ (Fig. 5D). In SCG neurons microinjected with $100 \mathrm{ng} / \mu \mathrm{l} \mathrm{hCB1}$ cDNA, SR 141716A increased the $\mathrm{Ca}^{2+}$ current $75.1 \pm 13.3 \%$ $(n=4)$ (Fig. $5 D)$. Thus, there are more tonically active hCB1 receptors in SCG neurons microinjected with $100 \mathrm{ng} / \mu \mathrm{l} \mathrm{hCB} 1$ cDNA than in neurons microinejcted with $50 \mathrm{ng} / \mu \mathrm{l} \mathrm{hCB} 1 \mathrm{cDNA}$. These results lend support to the idea that the tonically active state of the hCB1 receptor can sequester G-proteins. However, not all hCB1 receptors are tonically active because the cannabinoid agonist WIN 55,212-2 can still decrease the $\mathrm{Ca}^{2+}$ current. 


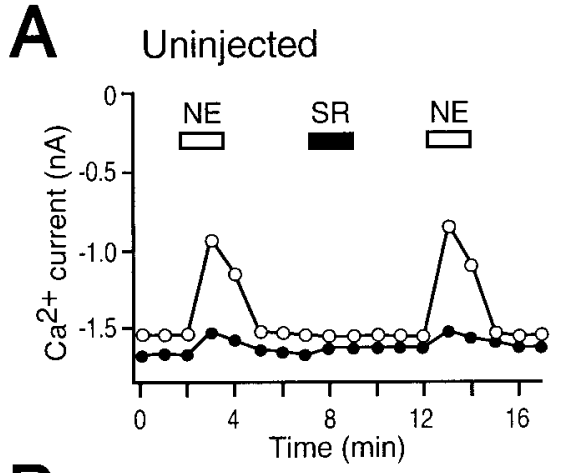

B
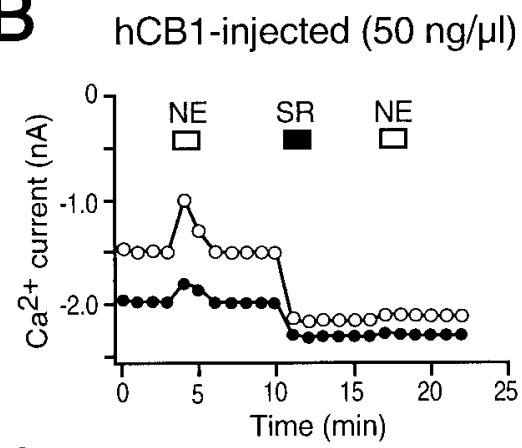

C

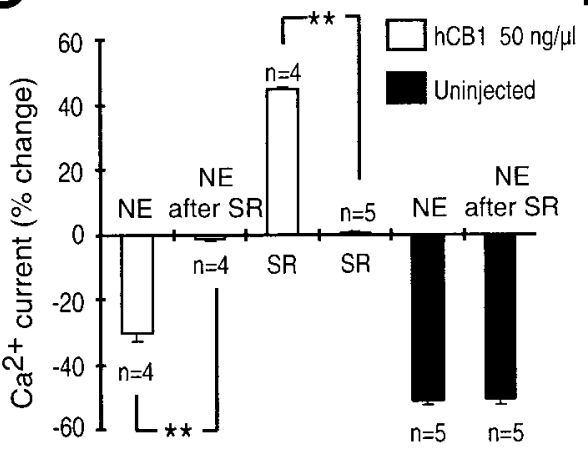

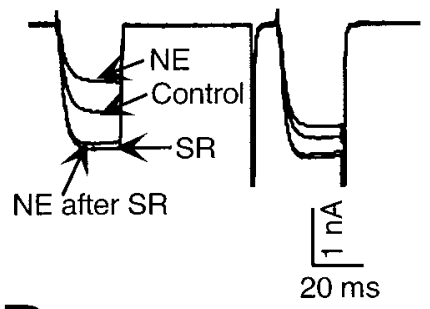

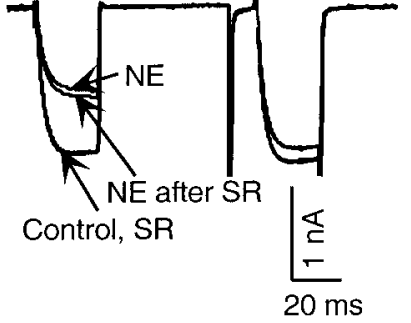

D

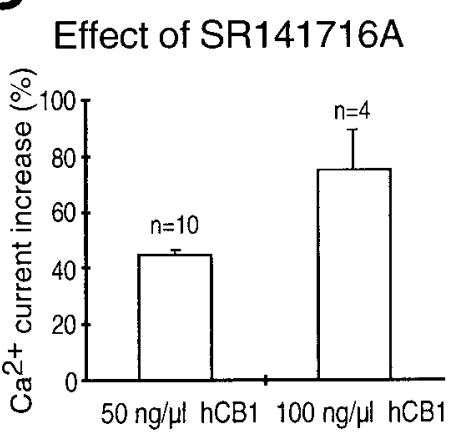

Figure 5. The cannabinoid receptor inverse agonist SR $141716 \mathrm{~A}$ blocks the effect of norepinephrine on the $\mathrm{Ca}^{2+}$ current. $A$, Application of $10 \mu \mathrm{M}$ norepinephrine ( $N E$, open bar) inhibited the $\mathrm{Ca}^{2+}$ current in an uninjected SCG neuron. A subsequent application of $1 \mu \mathrm{M}$ SR 141716A ( $S R$, filled bar) had no effect on the $\mathrm{Ca}^{2+}$ current. A second application of norepinephrine again inhibited the $\mathrm{Ca}^{2+}$ current. Right, Superimposed current traces in the absence (Control) and in the presence of norepinephrine $(N E)$, SR 141716A $(S R)$, and again in the presence of norepinephrine ( $N E$ after $S R$ ). B, In an SCG neuron microinjected with $50 \mathrm{ng} / \mu \mathrm{l} \mathrm{hCB} 1 \mathrm{cDNA}$, norepinephrine ( $N E$, open bar) reversibly decreased the $\mathrm{Ca}^{2+}$ current. A subsequent application of $1 \mu \mathrm{M}$ SR 141716A (SR, filled bar) increased both the control (open circle) and facilitated (filled circle) $\mathrm{Ca}^{2+}$ current. The $\mathrm{Ca}^{2+}$ current remained enhanced after superfusion with external solution. A subsequent application of norepinephrine now failed to inhibit the $\mathrm{Ca}^{2+}$ current. Right, Superimposed current traces in the absence (Control $)$ and presence of the first application of norepinephrine $(N E)$, SR 141716A $(S R)$, and the second application of norepinephrine ( $N E$ after $S R$ ). $C$, Summary of the changes in the control $\mathrm{Ca}^{2+}$ current amplitude in uninjected SCG neurons ( filled bars) and in neurons microinjected with $50 \mathrm{ng} / \mu \mathrm{l}$ hCB1 cDNA (open bars). The effect of norepinephrine ( $N E$, open bar) was abolished $\left({ }^{* *} p<0.001\right)$ after the application of SR 141716A (NE after SR, open bar). SR 141716A significantly increased $\left({ }^{* *} p<0.001\right)$ the $\mathrm{Ca}^{2+}$ current in neurons microinjected with $50 \mathrm{ng} / \mu \mathrm{l} \mathrm{hCB} 1 \mathrm{cDNA}$ (SR, open bar) compared to uninjected SCG neurons (SR, filled bar). SR 141716A (NE after SR, filled bar) had no effect on the $\mathrm{Ca}^{2+}$ current inhibition by norepinephrine (NE, filled bar) in uninjected neurons. Number of neurons tested is indicated. $D$, SR $141716 \mathrm{~A}$ increased the control $\mathrm{Ca}^{2+}$ current to a greater extent in SCG neurons microinjected with $100 \mathrm{ng} / \mu \mathrm{l} \mathrm{hCB} 1 \mathrm{cDNA}$ than in neurons microinjected with $50 \mathrm{ng} / \mu \mathrm{l}$ hCB1 cDNA. The number of neurons tested is indicated.
These results suggest that hCB1 receptors have a high affinity for a limited pool of $\mathrm{G}_{\mathrm{i} / \mathrm{o}}$-proteins in their GDP-bound form. The hCB1 receptor interconverts between an inactive state coupled to $\mathrm{G}_{\mathrm{i} / \mathrm{o}}$ in its GDP-bound form and an active state coupled to $\mathrm{G}_{\mathrm{i} / \mathrm{o}}$ in its GTP-bound form. The agonist stabilizes the receptor in its active state coupled to $\mathrm{G}_{\mathrm{i} / \mathrm{o}}$ in its GTP-bound form.

\section{Rescue of $N E$ effects by $G$-proteins}

We hypothesized that we could rescue NE signaling in neurons expressing hCB1 receptors by expression of $\mathrm{G}_{\mathrm{i} / \mathrm{o}}$-proteins. To test this hypothesis, nuclei of individual SCG neurons were coinjected with $100 \mathrm{ng} / \mu \mathrm{l}$ each of hCB1, G $\alpha_{\mathrm{oB}}, \mathrm{G} \beta_{1}$, and $\mathrm{G} \gamma_{3} \mathrm{cDNAs}$ and 10 $\mathrm{ng} / \mu \mathrm{l}$ green fluorescent protein cDNA. NE decreased the $\mathrm{Ca}^{2+}$ current in control, uninjected neurons $55.4 \pm 1.8 \%(n=4)$. The effect of NE was abolished in neurons injected with hCB1 cDNA $(0.8 \pm 1.3 \% ; n=8)$. In neurons coinjected with $\mathrm{hCB} 1, \mathrm{G}_{\alpha \mathrm{oB}}, \mathrm{G}_{\beta 1}$, and $\mathrm{G}_{\gamma 3}$ cDNAs WIN 55,212-2 (1 $\left.\mu \mathrm{M}\right)$ inhibited the $\mathrm{Ca}^{2+}$ current $45.0 \pm 2.0 \%(n=4)$, and the effect of NE $(10 \mu \mathrm{M})$ was restored to $46.0 \pm 2.4 \%(n=4)$ (Fig. 6).

\section{DISCUSSION}

We found that expression of hCB1 cannabinoid receptors can sequester $\mathrm{G}_{\mathrm{i} / \mathrm{o}}$-proteins and prevent signaling by $\alpha_{2}$-adrenergic and somatostatin receptors. Sequestration of G-proteins could be rescued by expression of G-protein subunits, $\mathrm{G} \alpha_{\mathrm{oB}}, \mathrm{G} \beta_{1}$, and $\mathrm{G} \gamma_{3}$. $\mathrm{G}$-protein sequestration is specific to hCB1 because expression of another $\mathrm{G}_{\mathrm{i} / \mathrm{o}}$-coupled receptor, the mGluR2 metabotropic glutamate receptor, failed to have a similar effect. Expression of mGluR2 metabotropic glutamate receptors also indicates that it is unlikely that expression of hCB1 receptors alters the expression of $\alpha_{2}$-adrenergic or somatostatin receptors. Additionally, hCB1 receptors failed to alter the signaling of VIP receptors that couple to $\mathrm{G}_{\mathrm{s}}$-proteins (Zhu and Ikeda, 1994). Taken together, our results demonstrate that the ability to deplete a common pool of G-proteins is a property of hCB1 cannabinoid receptors and that sequestration of G-proteins is specific to the pertussis toxinsensitive $\mathrm{G}_{\mathrm{i} / \mathrm{o}}$-proteins.

Although it is possible that the complement of G-proteins expressed in SCG neurons may differ from central neurons, both SCG neurons expressing hCB1 receptors and hippocampal neurons with native $\mathrm{CB} 1$ receptors elicit a $\mathrm{Ca}^{2+}$ current inhibition that is pertussis toxin-sensitive (Pan et al., 1996; Twitchell et al., 1997). The precise complement, quantity, and localization of $\mathrm{G}_{\mathrm{i} / \mathrm{o}}$-proteins in hippocampal neurons are unknown, whereas immunoblot analysis has indicated the presence of $\mathrm{G} \alpha_{\mathrm{o}}$ in SCG 


\section{Effect of NE}

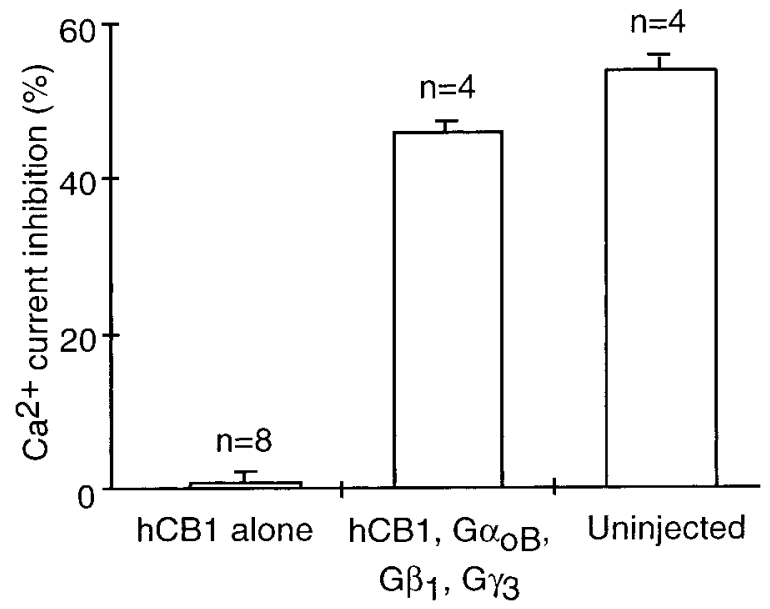

Figure 6. Expression of G-protein subunits rescues the effect of NE in cells expressing hCB1 receptors. Bar graph of control $\mathrm{Ca}^{2+}$ current inhibition by $10 \mu \mathrm{M}$ norepinephrine in uninjected SCG neurons (Uninjected), in SCG neurons injected with hCB1 cDNA ( $h C B 1)$, and in SCG neurons coinjected with $\mathrm{hCB} 1, \mathrm{G} \alpha_{\mathrm{oB}}, \mathrm{G} \beta_{1}$, and $\mathrm{G} \gamma_{3} \mathrm{cDNA}$ (hCB1, $\mathrm{G} \alpha_{\mathrm{oB}}$, $\left.\mathrm{G} \beta_{1}, \mathrm{G} \gamma_{3}\right)$. The effect of norepinephrine was rescued in hCB1 expressing neurons after coexpression of $\mathrm{G} \alpha_{\mathrm{oB}}, \mathrm{G} \beta_{1}$, and $\mathrm{G} \gamma_{3}$.

neurons (Caulfield et al., 1994). It remains possible that the quantity of $\mathrm{G}_{\mathrm{i} / \mathrm{o}}$-proteins in central neurons might differ from those in SCG neurons to such an extent that sequestration of $\mathrm{G}_{\mathrm{i} / \mathrm{o}}$-proteins by the CB1 cannabinoid receptor does not occur at all or to the same extent.

We have previously reported that SR 141716A acts as an inverse agonist in SCG neurons expressing hCB1 receptors (Pan et al., 1998). In the present study we found a greater effect of SR 141716A with increasing concentrations of hCB1 cDNA. SR 141716A increased the $\mathrm{Ca}^{2+}$ current $45 \%$ in neurons microinjected with $50 \mathrm{ng} / \mu \mathrm{l} \mathrm{hCB} 1 \mathrm{cDNA}$ and $75 \%$ with $100 \mathrm{ng} / \mu \mathrm{l} \mathrm{hCB} 1$ cDNA. Thus, the magnitude of the effect of SR 141716A depends on the abundance of tonically active hCB1 receptors, which is increased with increasing cDNA concentrations. If it is this tonically active state of the $\mathrm{hCB} 1$ receptor that can sequester G-proteins, then interference with norepinephrine and somatostatin signaling should depend on the concentration of hCB1 cDNA injected.

In SCG neurons microinjected with $100 \mathrm{ng} / \mu \mathrm{l} \mathrm{hCB1} \mathrm{cDNA,} \mathrm{the}$ inhibition of $\mathrm{Ca}^{2+}$ currents by norepinephrine and somatostatin was completely abolished; whereas, in neurons microinjected with $50 \mathrm{ng} / \mu \mathrm{l} \mathrm{hCB1} \mathrm{cDNA}$ the response to norepinephrine and somatostatin was significantly reduced, but not abolished. These results indicate that hCB1 receptors can disrupt signaling by other pertussis toxin-sensitive G-protein-coupled receptors and that the magnitude of this disruption depends on the abundance of hCB1 receptors.

Felder et al. (1995) reported that the effects of oxotremorine-M and somatostatin on activation of an inwardly rectifying $\mathrm{K}^{+}$ current were abolished in cells expressing $7.6 \mathrm{pmol} / \mathrm{mg}$ protein of the CB2 cannabinoid receptor but were unaffected when the density was $189 \mathrm{fmol} / \mathrm{mg}$ protein. In cells expressing $800 \mathrm{fmol} / \mathrm{mg}$ protein of the CB1 receptor both WIN 55,212-2 and oxotremorine-M inhibited the $\mathrm{Ca}^{2+}$ current. These results indicate that $\mathrm{CB} 2$ receptors at $7.6 \mathrm{pmol} / \mathrm{mg}$ protein can disrupt signaling by other G-protein-coupled receptors, but that $\mathrm{CB} 1$ receptors at $800 \mathrm{fmol} / \mathrm{mg}$ protein do not disrupt signaling. Bouaboula et al. (1997) found SR 141716A to be an inverse agonist that could sequester $\mathrm{G}_{\mathrm{i} / \mathrm{o}}$-proteins in cells expressing hCB1 receptors at a density of $2 \mathrm{pmol} / \mathrm{mg}$ protein. Landsman et al. (1997) also found tonically active hCB1 receptors in cells expressing $2.6 \mathrm{pmol} / \mathrm{mg}$ protein hCB1 receptors. Although the density of hCB1 receptors expressed in SCG neurons in our study is unknown, hCB1 receptors were tonically active in all neurons that showed a significant inhibition of signaling by other $\mathrm{G}_{\mathrm{i} / \mathrm{o}^{-}}$ coupled receptors. Thus, it is reasonable to expect that hCB1 receptor densities greater than or equal to $2 \mathrm{pmol} / \mathrm{mg}$ protein would disrupt signaling by $\mathrm{G}_{\mathrm{i} / \mathrm{o}}$-coupled receptors. In vivo, $\mathrm{CB} 1$ cannabinoid receptors are predominantly expressed in the substantia nigra, globus pallidus, olfactory bulb, cerebellum, and hippocampus (Herkenham et al., 1990, 1991a,b; Matsuda et al., 1993; Tsou et al., 1998). Cannabinoid receptor density in the substantia nigra of the rat brain was $6.3 \mathrm{pmol} / \mathrm{mg}$ protein, and in the hippocampal dentate gyrus molecular layer, the density was $4.1 \mathrm{pmol} / \mathrm{mg}$ (Herkenham et al., 1991a). Thus, neurons in the substantia nigra and hippocampus contain sufficiently high levels of $\mathrm{CB} 1$ receptors to sequester $\mathrm{G}_{\mathrm{i} / \mathrm{o}}$ and disrupt signaling by $\mathrm{G}_{\mathrm{i} / \mathrm{o}}$-coupled receptors.

Bouaboula et al. (1997) reported that SR 141716A blocked the stimulation of mitogen-activated protein kinase by the pertussis toxin-sensitive receptor-tyrosine kinases insulin and insulin-like growth factor 1 . They hypothesized that SR 141716 A converted a tonically active hCB1 receptor to a suppressor receptor coupled to $\mathrm{G}_{\mathrm{GDP}}$. To determine whether the inverse agonist-trapped inactive state could sequester $\mathrm{G}_{\mathrm{i} / \mathrm{o}}$-proteins from a common pool, we tested SCG neurons microinjected with $50 \mathrm{ng} / \mu \mathrm{l} \mathrm{hCB1} \mathrm{cDNA}$. In neurons microinjected with this concentration of hCB1 cDNA, norepinephrine inhibited the $\mathrm{Ca}^{2+}$ current by $30 \%$. The effect of norepinephrine was subsequently abolished after application of the CB1 cannabinoid receptor inverse agonist SR 141716A. The $\mathrm{G}_{\mathrm{i} / \mathrm{o}}$-proteins initially available to couple to the $\alpha_{2}$-adrenergic receptor were, within minutes, no longer available. Similar results were obtained for somatostatin. Our results demonstrate that $\mathrm{G}_{\mathrm{i} / \mathrm{o}}$-proteins are able to move freely between the $\alpha_{2}$-adrenergic or somatostatin receptors and the hCB1 cannabinoid receptors. SR 141716A stabilizes the inactive state, and the hCB1 receptors accumulate in this state. The successful competition of hCB1 receptors for $\mathrm{G}_{\mathrm{i} / \mathrm{o}}$-proteins suggests that hCB1 receptors in their inactive state have a higher affinity for $\mathrm{G}_{\mathrm{i} / \mathrm{o}}$-proteins than $\alpha_{2}$ adrenergic or somatotstatin receptors. Stabilization by SR 141716A of inactive hCB1 receptors precoupled to $\mathrm{G}_{\mathrm{i} / \mathrm{o}}$ blocked access to $\mathrm{G}_{\mathrm{i} / \mathrm{o}}$ by $\alpha_{2}$-adrenergic or somatostatin receptors.

In neurons microinjected with $100 \mathrm{ng} / \mu \mathrm{l} \mathrm{hCB} 1 \mathrm{cDNA}$ the response to either norepinephrine or somatostatin was completely abolished, suggesting that $\mathrm{G}_{\mathrm{i} / \mathrm{o}}$-proteins were unavailable to interact with these receptors. However, the cannabinoid agonist WIN 55,212-2 inhibited the $\mathrm{Ca}^{2+}$ current $45 \%$, indicating that a population of $\mathrm{hCB} 1$ receptors were originally in an inactive state. $\mathrm{G}_{\mathrm{i} / \mathrm{o}}$-proteins were available to couple to hCB1 receptors but not to $\alpha_{2}$-adrenergic or somatostatin receptors. These results indicate that hCB1 receptors also exist in an inactive state precoupled to $\mathrm{G}_{\mathrm{i} / \mathrm{o}}$-proteins and that hCB1 receptors must have a greater affinity for $\mathrm{G}_{\mathrm{i} / \mathrm{o}}$-proteins than $\alpha_{2}$-adrenergic and somatostatin receptors. Cannabinoid receptors also have a greater affinity for $\mathrm{G}_{\mathrm{i} / \mathrm{o}}$-proteins than mGluR2 metabotropic glutamate receptors whose expression did not affect signaling by $\alpha_{2}$ adrenergic and somatotstatin receptors.

Our results are consistent with a model in which hCB1 canna- 

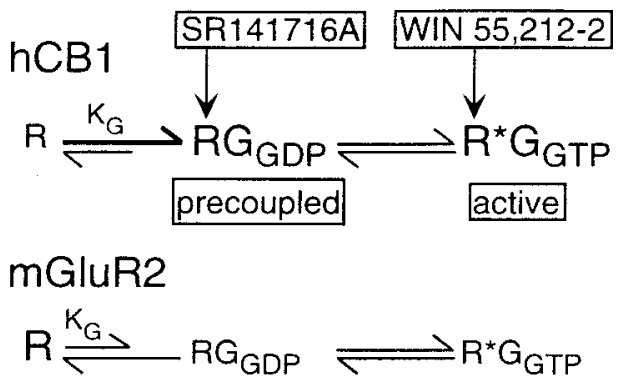

Figure 7. Model of hCB1 cannabinoid and mGluR2 metabotropic glutamate receptor states. The hCB1 cannabinoid receptor has a high association constant, $K_{G}$, between the inactive receptor $R$ and $G_{i / o}$-proteins in their inactive GDP-bound state. Therefore, the hCB1 receptor has a high probability of being in an inactive state precoupled to G-proteins, the $\mathrm{RG}_{\mathrm{GDP}}$ state. The inverse agonist SR 141716A has a high affinity for the inactive $R_{G}$ GDP state and acts to stabilize this state. The hCB1 receptor can also exist in a tonically active state coupled to active G-proteins in their GTP-bound state. This active $\mathrm{R}^{*} \mathrm{G}_{\mathrm{GTP}}$ state of the receptor has a high affinity for the cannabinoid agonist WIN 55,212-2. Therefore, hCB1 receptors exist predominantly in two states: the $\mathrm{RG}_{\mathrm{GDP}}$ state and the $\mathrm{R} * \mathrm{G}_{\mathrm{GTP}}$ state. In contrast, the mGluR2 metabotropic glutamate receptor has a small association constant, $\mathrm{K}_{\mathrm{G}}$, between the receptor and the $G_{i / 0}$-proteins and thus has a lower probability of existing in the $R_{G D P}$ state. The mGluR2 receptor also does not exhibit tonic receptor activity. Therefore, the mGluR2 receptor would exist predominantly in an inactive $\mathrm{R}$ state not coupled to a G-protein.

binoid receptors exist predominantly in two states, an inactive $\mathrm{R}$ state precoupled to $\mathrm{G}_{\mathrm{i} / \mathrm{o}}$ in its GDP-bound form and an active $\mathrm{R}^{*}$ state coupled to $\mathrm{G}_{\mathrm{i} / \mathrm{o}}$ in its GTP-bound form (Fig. 7). The active $\mathrm{R}^{*}-\mathrm{G}_{\mathrm{GTP}}$ state would have a higher affinity for the cannabinoid agonist WIN 55,212-2. The inactive $\mathrm{R}-\mathrm{G}_{\mathrm{GDP}}$ state would have a higher affinity for the cannabinoid inverse agonist SR 141716A. Both the active $R *-G_{G T P}$ state and the inactive $R-G_{G D P}$ state can sequester G-proteins. This model is not inconsistent with the cubic ternary complex model for G-protein-coupled receptors (Kenakin, 1996). The cubic ternary complex model includes a stable complex between an inactive receptor and a G-protein. Kenakin (1996) proposed an inactive receptor G-protein complex, even though there was no evidence for its existence. Consequently, Kenakin (1996) proposed that the association constant between the inactive receptor and $\mathrm{G}$-protein, $\mathrm{K}_{\mathrm{G}}$, must be very small. Our results provide evidence that the inactive hCB1 receptor can form a stable complex precoupled with $\mathrm{G}_{\mathrm{i} / \mathrm{o}}$. For precoupling to occur, the hCB1 association constant, $\mathrm{K}_{\mathrm{G}}$, must be large. The magnitude of $\mathrm{K}_{\mathrm{G}}$ between the receptor and $\mathrm{G}$-protein is the major difference between cannabinoid receptors, including both CB1 and CB2 (Bouaboula et al., 1999) and other G-proteincoupled receptors such as the mGluR2 metabotropic glutamate receptor (Fig. 7). This means that cannabinoid receptors would exist predominantly in either a G-protein-precoupled inactive $\mathrm{R}-\mathrm{G}_{\mathrm{GDP}}$ state or an active $\mathrm{R}^{*}-\mathrm{G}_{\mathrm{GTP}}$ state. This model differs from the three-state receptor model proposed by Bouaboula et al. (1997). According to their three-state receptor model, SR 141716A converts a tonically active hCB1 receptor into an active negative state in which the receptor is coupled to $G_{i / o}$ in its GDP-bound form. We observed the existence of an inactive hCB1 receptor precoupled to $\mathrm{G}_{\mathrm{GDP}}$. This naturally occurring inactive $\mathrm{R}-\mathrm{G}_{\mathrm{GDP}}$ state of the receptor would have a high affinity for SR 141716A, and SR 141716A would act to stabilize the inactive $\mathrm{R}-\mathrm{G}_{\mathrm{GDP}}$ state of the receptor.

In summary, we have shown that the human CB1 cannabinoid receptor has the ability to block signaling by other pertussis toxin-sensitive $\mathrm{G}_{\mathrm{i} / \mathrm{o}}$-coupled receptors by sequestering a common pool of $\mathrm{G}_{\mathrm{i} / \mathrm{o}}$-proteins. Sequestration of $\mathrm{G}$-proteins by CB1 cannabinoid receptors likely occurs in two receptor states, an inactive $\mathrm{R}-\mathrm{G}_{\mathrm{GDP}}$ state and an active $\mathrm{R}^{*}-\mathrm{G}_{\mathrm{GTP}}$ state. Our study suggests that $\mathrm{CB} 1$ cannabinoid receptors may act as dominant receptors controlling the biological signals of other pertussis toxin-sensitive $\mathrm{G}_{\mathrm{i} / \mathrm{o}}$-coupled receptors.

\section{REFERENCES}

Bouaboula M, Perrachon S, Milligan L, Canat X, Rinaldi-Carmona M, Portier M, Barth F, Calandra B, Pecceu F, Lupker J, Maffrand JP, Le Fur G, Casellas P (1997) A selective inverse agonist for central cannabinoid receptor inhibits mitogen-activated protein kinase activation stimulated by insulin or insulin-like growth factor 1 . Evidence for a new model of receptor/ligand interactions. J Biol Chem 272:22330-22339.

Bouaboula M, Desnoyer N, Carayon P, Combes T, Casellas P (1999) $\mathrm{G}_{\mathrm{i}}$-protein modulation induced by a selective inverse agonist for the peripheral cannabinoid receptor CB2: implications for intracellular signalization cross-regulation. Mol Pharmacol 55:473-480.

Caulfield MP, Jones S, Vallis Y, Buckley NJ, Kim GD, Milligan G, Brown DA (1994) Muscarinic M-current inhibition via $G \alpha$ q/11 and $\alpha$-adrenoceptor inhibition of $\mathrm{Ca}^{2+}$ current via $\mathrm{G} \alpha \mathrm{o}$ in rat sympathetic neurones. J Physiol (Lond) 15:415-422.

Coutts AA, Pertwee RG (1997) Inhibition by cannabinoid receptor agonists of acetylcholine release from the guinea-pig myenteric plexus. Br J Pharmacol 121:1557-1566.

Deadwyler SA, Hampson RE, Bennett BA, Edwards TA, Mu J, Pacheco MA, Ward SJ, Childers SR (1993) Cannabinoids modulate potassium current in cultured hippocampal neurons. Receptors Channels $1: 121-134$

Deadwyler SA, Hampson RE, Mu J, Whyte A, Childers S (1995) Cannabinoids modulate voltage sensitive potassium A-current in hippocampal neuron via a cAMP-dependent process. J Pharmacol Exp Ther 273:734-743.

Felder CC, Joyce KE, Briley EM, Mansouri J, Mackie K, Blond O, Lai Y, Ma AL, Mitchell RL (1995) Comparison of the pharmacology and signal transduction of the human cannabinoid $\mathrm{CB}_{1}$ and $\mathrm{CB}_{2}$ receptors. Mol Pharmacol 48:443-450.

Gérard CM, Mollereau C, Vassart G, Parmentier M (1991) Molecular cloning of a human cannabinoid receptor which is also expressed in testis. Biochem J 279:129-134.

Gifford AN, Ashby CR (1996) Electrically evoked acetylcholine release from hippocampal slices is inhibited by the cannabinoid receptor agonist, WIN 55212-2, and is potentiated by the cannabinoid antagonist, SR 141716A. J Pharmacol Exp Ther 277:1431-1436.

Hamill OP, Marty A, Neher E, Sakmann B, Sigworth FJ (1981) Improved patch-clamp techniques for high-resolution current recording from cells and cell-free membrane patches. Pflügers Arch 391:85-100.

Herkenham M, Lynn AB, Little MD, Johnson MR, Melvin LS, De Costa BR, Rice KC (1990) Cannabinoid receptor localization in brain. Proc Natl Acad Sci USA 87:1932-1936.

Herkenham M, Lynn AB, Johnson MR, Melvin LS, de Costa BR, Rice KC (1991a) Characterization and localization of cannabinoid receptors in rat brain: a quantitative in vitro autoradiographic study. J Neurosci 11:563-583.

Herkenham M, Lynn AB, de Costa BR, Richfield EK (1991b) Neuronal localization of cannabinoid receptors in the basal ganglia of the rat. Brain Res 547:267-274.

Ikeda SR, Schofield GG (1989) Somatostatin blocks a calcium current in rat sympathetic ganglion neurons. J Physiol (Lond) 409:221-240.

Ikeda SR, Lovinger DM, McCool BA, Lewis DL (1995) Heterologous expression of metabotropic glutamate receptors in adult rat sympathetic neurons: subtype-specific coupling to ion channels. Neuron 14:1029-1038.

Ishac EJN, Jiang L, Lake KD, Varga K, Abood ME, Kunos G (1996) Inhibition of exocytotic noradrenaline release by presynaptic cannabinoid CB1 receptors on peripheral sympathetic nerves. Br J Pharmacol 118:2023-2028.

Katona I, Sperlágh B, Sík A, Käfalvi A, Vizi ES, Mackie K, Freund TF (1999) Presynaptically located CB1 cannabinoid receptors regulate GABA release from axon terminals of specific hippocampal interneurons. J Neurosci 19:4544-4558.

Kenakin T (1996) The classification of seven transmembrane receptors in recombinant expression systems. Pharmacol Rev 48:413-463. 
Landsman RS, Burkey TH, Consroe P, Roeske WR, Yamamura HI (1997) SR 141716A is an inverse agonist at the human cannabinoid $\mathrm{CB}_{1}$ receptor. Eur J Pharmacol 334:R1-R2.

Mackie K, Lai Y, Westenbroek R, Mitchell R (1995) Cannabinoids activate an inwardly rectifying potassium conductance and inhibit Q-type calcium currents in AtT20 cells transfected with rat brain cannabinoid receptor. J Neurosci 15:6552-6561.

MacLennan SJ, Reynen PH, Kwan J, Bonhaus DW (1998) Evidence for inverse agonism of SR141716A at human recombinant cannabinoid CB1 and CB2 receptors. Br J Pharmacol 124:619-622.

Matsuda LA, Lolait SJ, Brownstein MJ, Young AC, Bonner TI (1990) Structure of a cannabinoid receptor and functional expression of the cloned cDNA. Nature (Lond) 346:561-564.

Matsuda LA, Bonner TI, Lolait SJ (1993) Localization of cannabinoid receptor mRNA in rat brain. J. Comp. Neurol. 327:535-550.

Pan X, Ikeda SR, Lewis DL (1996) Rat brain cannabinoid receptor modulates $\mathrm{N}$-type $\mathrm{Ca}^{2+}$ channels in a neuronal expression system. Mol Pharmacol 49:707-714.

Pan X, Ikeda SR, Lewis DL (1998) SR 141716A acts as an inverse agonist to increase neuronal voltage-dependent $\mathrm{Ca}^{2+}$ currents by reversal of tonic CB1 cannabinoic receptor activity. Mol Pharmacol 54:1064-1072.
Rinaldi-Carmona M, Barth F, Héaulme M, Shire D, Calandra B, Congy C, Martinez S, Maruani J, Néliat G, Caput D, Ferrara P, Soubrié P, Brelière JC, Le Fur G (1994) SR141716A, a potent and selective antagonist of the brain cannabinoid receptor. FEBS Lett 350:240-244.

Schofield GG (1990) Norepinephrine blocks a calcium current of adult rat sympathetic neurons via an $\alpha_{2}$-adrenoceptor. Eur. J. Pharmacol. 180:37-47.

Schofield GG (1991) Norepinephrine inhibits a $\mathrm{Ca}^{2+}$ current in rat sympathetic neurons via a G-protein. Eur J Pharmacol 207:195-207.

Shen M, Thayer SA (1998) The cannabinoid agonist Win55,212-2 inhibits calcium channels by receptor-mediated and direct pathways in cultured rat hippocampal neurons. Brain Res 783:77-84.

Tsou K, Brown S, Sanudo-Pena, Mackie K, Walker JM (1998) Immunohistochemical distribution of cannabinoid CB1 receptors in the rat central nervous system. Neuroscience 83:393-411.

Twitchell W, Brown S, Mackie K (1997) Cannabinoids inhibit N- and $\mathrm{P} / \mathrm{Q}$-type calcium channels in cultured rat hippocampal neurons. J Neurophysiol 78:43-50.

Zhu Y, Ikeda SR (1994) VIP inhibits N-type $\mathrm{Ca}^{2+}$ channels of sympathetic neurons via a pertussis toxin-insensitive but cholera toxinsensitive pathway. Neuron 13:657-669. 